\title{
Effect of Ginger Rhizomes Extracts on Keeping Quality and Oxidative Stability of UF-White Soft Cheese \\ El-Zawahry, A. A. ${ }^{1}$ and E. M. Abd El-Wahed ${ }^{2}$ \\ ${ }^{1}$ Animal Production Research Institute, Agricultural Research Center, Ministry of Agriculture, Dokki, Egypt. \\ ${ }^{2}$ Food Science Department, Faculty of Agriculture, Zagazig University, 44511 Zagazig, Egypt. \\ E-mail address (elzawahry60@yahoo.com)
}

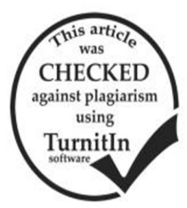

\section{ABSTRACT}

The present study was carried out to estimate the effect of ginger rhizomes (Zingiber officinale) extracts on the oxidative stability, chemical composition, microbiological and sensory properties of UF-soft cheese being made with aqueous or ethanolic ginger extracts (1\%) compared to control cheese and cheese contained $0.02 \%$ of butylated hydroxy anisole (BHA). Resultant cheeses were stored in brine solution $6 \%$ at $7 \pm 1{ }^{\circ} \mathrm{C}$ up to 90 days. Results showed that, addition of ginger rhizomes extracts had increasing significant effect $(\mathrm{P} \leq 0.05)$ on fat/DM\%, soluble nitrogen ( $\mathrm{SN} / \mathrm{TN} \%)$ and non protein nitrogen (NPN/TN\%). On the other hand, titratable acidity, total protein $\%$, salt in moisture $\%$ and total volatile fatty acids (TVFAs) were decreased with addition of aqueous or ethanolic ginger extracts compared to control cheese and cheese treated with BHA as synthetic antioxidant. Cheese containing $1 \%$ ethanolic extract showed the highest oxidative stability. Also, ginger extracts reduced the total bacterial count than the control and BHA treatment. However, yeast and mould counts showed opposite trend and they were not detected in all treated samples up to 60 days of storage. Also, results showed that, cheese samples containing ginger ethanolic extract (1\%) showed better organoleptic characteristics than other treatments. From the previous it is advanced to use ginger extract in manufacture of white soft cheese at the rate of $(1 \%)$.

Keywords: Ginger rhizomes, Butylated hydroxy anisole, UF-soft cheese and natural antioxidant.

\section{INTRODUCTION}

Antioxidants are major ingredients that protect the quality of oils and fats by retarding oxidation (Jang et al., 2012 and Abdulla et al., 2007). There are some serious problems concerning the safety and toxicity of synthetic antioxidants related to their metabolism and possible absorption and accumulation in body organs and tissues (Ajila et al., 2007). Therefore, the using of natural antioxidants is highly desirable. Natural anti-oxidative compounds are found in numerous plant materials such as oil seeds, cereal crops, vegetables, fruits, leaves, breaks and roots, spices and herbs (Yean and Phillip, 2004). Many studies showed that natural antioxidants as flavonoids and other phenolic phytochemical present in plants are associated with reduced chronic disease risk (Bandyopadhyay et al., 2008). Natural products (without any synthetic antioxidant) and health food have to be give a lot of interests for enhancing overall well-being, in the prevention of diseases and also in the incorporation of health-promoting substances into the diet as natural food additives (Prassad et al., 2012). Some studies referred to that ginger has been used in herbal medicine practice for the treatment of arthritis, rheumatologic conditions and muscular discomfort (Grant and Lutz, 2000). Liang (1992) showed that Ginger has also been suggested for the treatment of various other conditions, including Atherosclerosis, migraine headaches, rheumatoid arthritis, high cholesterol, ulcers, depression, and impotence. In addition to these medicinal uses, ginger continues to be valued around the world as an important cooking spice and is believed to help against common cold, flu-like symptoms, and even painful menstrual periods. The recent research activities are focused on finding natural sources of antioxidants as consumers are more conscious about their diet, white, synthetic antioxidants are being restricted due to their carcinogenicity. So there is growing trend in searching for antioxidants of natural origin. Medicinal plants is one a good sources rich in natural antioxidants and phenolics which progressively applied in dairy food manufacturing in order to improve nutritional and therapeutic properties (Shori and Baba 2011a\&b;
Karaaslan et al., 2011; Martins et al., 2014 and Bertolino et al., 2015).

Soft cheese is one of the most common appreciated cheese in middle eastern countries. This type of cheese is produced their by enzymatic or acidic coagulation of fresh milk (buffalos' or cow's milk) or reconstituted skim milk powder with oils, (Ramadan et al., 2014). Also it can be made with the addition of starter culture to cheese milk.

The present study is planned to improve the keeping quality and oxidative stability of UF-white soft cheese affected using ginger extract as a natural antioxidant.

\section{MATERIALS AND METHODS}

Materials:

Fresh ginger rhizomes (Zingiber officinale) were obtained from local market in Zagazig City, Egypt. Retentate of buffalo's milk ( $40 \%$ solids), was obtained from Obour Land Company for food industries. Freeze dried FDDVS YF-L812® cultures containing Lactobacillus delbrueckii subsp. bulgaricus and Streptococcus thermophilus and microbial rennet, CHY-MAX ${ }^{\circledR}$ Powder Extra NB (Activity $\approx 2235 \mathrm{IMCU} / \mathrm{g}$, Dosage: $0.022 \mathrm{~g} \approx 50$ IMCU/ L milk, were obtained from Chr. Hansen's, Copenhagen, Denmark. Sodium chloride and calcium chloride were obtained from El-Gomhoria Company, Cairo. Butylated hydroxy anisole (BHA) obtained from Sigma (St. Louis, Mo, USA).

\section{Methods:}

Preparation of ultrafiltrated milk retentate:

Fresh standardized buffalo's milk ( $6 \%$ fat) was pasteurized at $75^{\circ} \mathrm{C}$ for 5 second, cooled to $37^{\circ} \mathrm{C}$ and separated to skim milk and sweet cream, then the skim milk ultrafiltrated at $50^{\circ} \mathrm{C}$ using an APV unit at pressure of $2 \mathrm{Mpa}$ and the cream was added to the resultant retentate at the dairy processing unit, Food Science Department, Faculty of Agriculture, Zagazig University.

Preparation of aqueous and ethanolic ginger rhizomes extracts:

Fresh ginger rhizomes was washed, peeled, cut into small pieces and dried at $55^{\circ} \mathrm{C}$ for $24 \mathrm{hr}$. in the oven and 
converted to powder using grinder. $10 \mathrm{~g}$ of ginger rhizomes powder was extracted with $100 \mathrm{ml}$ of distilled water or ethanol $80 \%$ as described by Rehman, et al., 2003.

\section{Cheese manufacture:}

Buffalos' milk retentate containing $0.02 \% \mathrm{CaCl}_{2}$ and $4 \% \mathrm{NaCl}$ was divided into four equal portions. The first portion without any additives (control). The Butylated hydroxyl anisole (BHA) as synthetic antioxidant was added to the second portion at ratio of $0.02 \%$. Aqueous and ethanolic ginger extracts were added to the third and fourth portion respectively at a ratio of $1 \%$. White soft cheese was made by the method of (Renner and Abd El-Salam 1991). The resultant cheese treatments were stored in brine solution $6 \%$ at $7 \pm 1{ }^{\circ} \mathrm{C}$ for 90 days, cheese samples were analyzed when fresh and after 30,60 and 90 days of storage period.

\section{Chemical Analyses:}

White soft cheese was chemically analyzed for total solids, fat, salt in moisture, titratable acidity, total protein, soluble nitrogen and non protein nitrogen contents were determined as described in the AOAC (2007). Total volatile fatty acids (TVFAs) were estimated according to Kosikowski (1986).

Oxidative stability tests:

Cheese fat was extracted from the samples according to Abd El-Fattah (2006). Peroxide and acid values of white soft cheese fat were determined according to AOAC (2007). Thiobarbituric acid content (TBA) of cheese fat was determined according to Keeny (1971).

Microbiological Examination:

Cheese samples were examined for total bacterial count, coliform and yeast \& mould counts according to American Public Health Association (APHA, 2005).

\section{Sensory properties of cheese:}

The sensory properties of cheese samples were assessed by 10 panel members of the Food Sci., Dept., Fac. Agric., Zagazig, Univ. for flavour (50) body and texture (40) and appearance (10) according to Scott (1981).

\section{Statistical analysis:}

Statistical analysis was done by treating data with SAS (2003) software programs (SAS Institute Inc., Cary, NC) $(\mathrm{P} \leq 0.05)$.

Table 1. Chemical composition of UF-soft cheese affected by addition of ginger extract.

\begin{tabular}{|c|c|c|c|c|c|c|}
\hline \multirow{2}{*}{ Properties } & \multirow{2}{*}{$\begin{array}{l}\text { Storage period } \\
\text { (days) }\end{array}$} & \multirow{2}{*}{ Control } & \multirow{2}{*}{$\begin{array}{c}\text { BHA } \\
(0.02 \%)\end{array}$} & \multicolumn{2}{|c|}{ Ginger extract (1\%) } & \multirow{2}{*}{ Significant } \\
\hline & & & & Aqueous extract & Ethanolic extract & \\
\hline \multirow{4}{*}{ Moisture \% } & Fresh & $64.50^{\mathrm{a}}$ & $66.34^{\mathrm{a}}$ & $66.15^{\mathrm{a}}$ & $66.20^{\mathrm{a}}$ & $* * *$ \\
\hline & 30 & $62.13^{\mathrm{c}}$ & $64.96^{\mathrm{a}}$ & $64.00^{\mathrm{b}}$ & $64.15^{\mathrm{b}}$ & $* * *$ \\
\hline & 60 & $60.30^{\mathrm{c}}$ & $63.70^{\mathrm{a}}$ & $63.12^{\mathrm{b}}$ & $63.25^{\mathrm{b}}$ & $* * *$ \\
\hline & 90 & $58.86^{\mathrm{d}}$ & $62.83^{\mathrm{a}}$ & $62.16^{\mathrm{c}}$ & $62.41^{\mathrm{b}}$ & $* * *$ \\
\hline \multirow{4}{*}{ Fat / D.M. \% } & Fresh & $45.76^{\mathrm{b}}$ & $45.81^{b}$ & $46.20^{\mathrm{a}}$ & $46.32^{\mathrm{a}}$ & $* * *$ \\
\hline & 30 & $46.80^{\mathrm{b}}$ & $46.97^{\mathrm{ab}}$ & $47.05^{\mathrm{ab}}$ & $47.16^{\mathrm{a}}$ & $*$ \\
\hline & 60 & $47.66^{\mathrm{c}}$ & $47.85^{\mathrm{b}}$ & $48.64^{\mathrm{a}}$ & $48.75^{\mathrm{a}}$ & $* * *$ \\
\hline & 90 & $51.45^{\mathrm{c}}$ & $51.73^{\mathrm{ab}}$ & $51.60^{\mathrm{bc}}$ & $51.84^{\mathrm{a}}$ & $* *$ \\
\hline \multirow{4}{*}{ Total Protein \% } & Fresh & $12.53^{\mathrm{a}}$ & $12.10^{\mathrm{c}}$ & $12.31^{b}$ & $12.26^{b}$ & $* * *$ \\
\hline & 30 & $12.67^{\mathrm{a}}$ & $12.35^{\mathrm{c}}$ & $12.48^{\mathrm{b}}$ & $12.40^{c}$ & $* * *$ \\
\hline & 60 & $12.84^{\mathrm{a}}$ & $12.60^{\mathrm{c}}$ & $12.72^{\mathrm{b}}$ & $12.65^{\mathrm{c}}$ & $* * *$ \\
\hline & 90 & $13.24^{\mathrm{a}}$ & $13.00^{\mathrm{c}}$ & $13.15^{\mathrm{b}}$ & $13.08^{b c}$ & $* * *$ \\
\hline \multirow{4}{*}{$\begin{array}{l}\text { Titratable acidity (as } \\
\text { lactic acid \%) }\end{array}$} & Fresh & $0.24^{\mathrm{a}}$ & $0.24^{\mathrm{a}}$ & $0.23^{\mathrm{a}}$ & $0.22^{\mathrm{a}}$ & NS \\
\hline & 30 & $0.82^{\mathrm{a}}$ & $0.81^{\mathrm{a}}$ & $0.77^{\mathrm{b}}$ & $0.73^{\mathrm{c}}$ & $* *$ \\
\hline & 60 & $1.41^{\mathrm{a}}$ & $1.40^{\mathrm{a}}$ & $1.34^{\mathrm{b}}$ & $1.27^{\mathrm{c}}$ & $* * *$ \\
\hline & 90 & $1.92^{\mathrm{a}}$ & $1.90^{\mathrm{a}}$ & $1.77^{\mathrm{b}}$ & $1.65^{\mathrm{c}}$ & $* * *$ \\
\hline \multirow{4}{*}{ Salt / moisture \% } & Fresh & $8.65^{\mathrm{a}}$ & $8.30^{b}$ & $8.20^{\mathrm{c}}$ & $8.25^{\mathrm{bc}}$ & $* * *$ \\
\hline & 30 & $9.76^{\mathrm{a}}$ & $9.50^{\mathrm{b}}$ & $9.38^{\mathrm{c}}$ & $9.42^{\mathrm{bc}}$ & $* * *$ \\
\hline & 60 & $10.12^{\mathrm{a}}$ & $9.92^{\mathrm{b}}$ & $9.81^{\mathrm{c}}$ & $9.84^{\mathrm{c}}$ & $* * *$ \\
\hline & 90 & $10.55^{\mathrm{a}}$ & $10.41^{\mathrm{b}}$ & $10.30^{\mathrm{c}}$ & $10.33^{c}$ & $* * *$ \\
\hline
\end{tabular}

$\overline{\mathrm{A}, \mathrm{b}, \mathrm{c}}$ Means in the same row with different superscripts differ significantly at $(\mathrm{P} \leq \mathbf{0 . 0 5})$

\section{RESULTS AND DISCUSSION}

Gross chemical composition of UF-white soft cheese:

Data in Table (1) show that, UF-white soft cheese containing aqueous or ethanolic ginger extracts had the highest moisture content followed by cheese treated with BHA $(0.02 \%)$ and control cheese respectively throughout the ripening periods. The moisture content of all cheese treatments were decreased during storage period. The decrease in moisture content of the resultant cheeses along the storage period may be due to the whey explosion resulting from acid development during storage period. Similar results were reported by Salem et al., (2010). Also, it could be observed that the fat/dry matter content of experimental cheese samples increased up to the end of storage period, depending on the loss of moisture. Cheese fortified with ginger extracts showed slightly higher in fat/DM $\%$ up to the end of storage compared to cheese samples containing BHA and control cheese. Similar results are found by Abd El-Aziz et al., (2012). Also, table (1) shows that, salt in moisture of all cheese treatments were increased with the progress in storage period. This could be attributed to the loss in water as a result of water exudation during storage period which in turn lead to a more salt concentration. There is no significance between cheese samples treated with ginger extracts, but observed significance $(p \leq 0.05)$ between control and other treatments. This results are in accordance with that obtained by Salem et al., (2010). The same table shows that, titratable acidity increased gradually until the end of storage period for all treatments. The control cheese samples had higher titratable acidity than all other cheese treatments during storage period. Cheese containing ginger extracts showed lower titratable acidity. This may be due to antimicrobial activity of these extracts (Prasad and Pushpa 2007; Monagas et al., 2009 and Elsohaimy 2014). Similar results were obtained by Abd El-Aziz et al., 2012 and Ruben et al., 2013. Also, the TP\% of cheese samples increased gradually up to the end of storage period and there were significant $(\mathrm{p} \leq 0.05)$ differences in TP\% along with the storage period. 
Ripening indices of cheese:

Table (2) shows that, SN/TN\% and NPN/TN\% of all cheese treatments gradually increased up to the end of storage period. This increase may be due to the break down occurred by the proteolytic enzymes. On the other hand, cheese samples containing ginger extracts was higher significantly $(\mathrm{p} \leq 0.05)$ proteolysis compared to cheese treated with BHA or control cheese. Cheese treated with ginger ethanolic extract was slightly higher proteolysis followed by cheese treated with ginger aqueous extract, cheese treated with BHA and control cheese respectively. This may be due to the proteolysis activity of ginger extract Hashim et al. (2011); Huang et al. (2011) and AbdEl-Aziz et al. (2012). Also, results indicated that TVFAs increased gradually of all cheese sample treatments with the progress of storage period. No significant differences $(\mathrm{p} \leq 0.05)$ TVFAs between control cheese and cheese containing BHA, while cheese sample containing ginger extracts had slightly decreased TVFAs compared to control cheese during storage period. The decrease of TVFAs in cheeses treated by ginger extracts may be attributed to ginger extract has high content of essential oil which is a mixture of monoterpenic and sesquiterpenic compounds, contains the volatile compounds responsible for the characteristic ginger flavor (Zancan et al., 2002). Similar results were obtained by Abd El-Aziz et al., (2012).

Table 2. Ripening indices of UF-soft cheese affected by addition of ginger extract.

\begin{tabular}{|c|c|c|c|c|c|c|}
\hline \multirow{2}{*}{ Properties } & \multirow{2}{*}{$\begin{array}{l}\text { Storage period } \\
\text { (days) }\end{array}$} & \multirow{2}{*}{ Control } & \multirow{2}{*}{$\begin{array}{c}\text { BHA } \\
(0.02 \%)\end{array}$} & \multicolumn{2}{|c|}{ Ginger extract (1\%) } & \multirow{2}{*}{ Significant } \\
\hline & & & & Aqueous extract & Ethanolic extract & \\
\hline \multirow{4}{*}{ S.N. / T.N. \% } & Fresh & $6.15^{\mathrm{b}}$ & $5.93^{\mathrm{c}}$ & $6.25^{\mathrm{a}}$ & $6.31^{\mathrm{a}}$ & $* * *$ \\
\hline & 30 & $11.24^{\mathrm{c}}$ & $11.05^{\mathrm{d}}$ & $11.41^{\mathrm{b}}$ & $11.57^{\mathrm{a}}$ & $* * *$ \\
\hline & 60 & $19.30^{\mathrm{c}}$ & $19.18^{\mathrm{d}}$ & $19.86^{\mathrm{b}}$ & $20.16^{\mathrm{a}}$ & $* * *$ \\
\hline & 90 & $25.72^{\mathrm{c}}$ & $25.66^{\mathrm{c}}$ & $26.00^{\mathrm{b}}$ & $26.32^{\mathrm{a}}$ & $* * *$ \\
\hline \multirow{4}{*}{ N.P.N / T.N. \% } & Fresh & $4.03^{\mathrm{c}}$ & $3.95^{\mathrm{d}}$ & $4.16^{\mathrm{b}}$ & $4.23^{\mathrm{a}}$ & $* * *$ \\
\hline & 30 & $7.72^{\mathrm{c}}$ & $7.70^{\mathrm{c}}$ & $7.95^{\mathrm{b}}$ & $8.15^{\mathrm{a}}$ & $* * *$ \\
\hline & 60 & $12.10^{\mathrm{c}}$ & $12.00^{\mathrm{d}}$ & $12.37^{\mathrm{b}}$ & $12.55^{\mathrm{a}}$ & $* * *$ \\
\hline & 90 & $12.43^{\mathrm{c}}$ & $12.40^{\mathrm{c}}$ & $12.60^{\mathrm{b}}$ & $12.81^{\mathrm{a}}$ & $* * *$ \\
\hline \multirow{4}{*}{$\begin{array}{l}\text { T.V.F.A. } \\
(\mathrm{NaOH} 0.1 \mathrm{~N} / 100 \mathrm{~g})\end{array}$} & Fresh & $11.25^{\mathrm{a}}$ & $11.30^{\mathrm{a}}$ & $11.28^{\mathrm{a}}$ & $11.32^{\mathrm{a}}$ & $* * *$ \\
\hline & 30 & $21.30^{\mathrm{a}}$ & $21.34^{\mathrm{a}}$ & $21.10^{\mathrm{b}}$ & $21.06^{\mathrm{b}}$ & $* * *$ \\
\hline & 60 & $27.42^{\mathrm{b}}$ & $27.53^{\mathrm{a}}$ & $27.21^{\mathrm{c}}$ & $27.14^{\mathrm{c}}$ & $* * *$ \\
\hline & 90 & $32.05^{\mathrm{a}}$ & $32.13^{\mathrm{a}}$ & $31.90^{\mathrm{b}}$ & $31.76^{\mathrm{c}}$ & $* * *$ \\
\hline
\end{tabular}

$\overline{A, b, c}$ Means in the same row with different superscripts differ significantly at $(\mathrm{P} \leq \mathbf{0 . 0 5})$

\section{Oxidative stability of cheese:}

Results presented in table (3) shows that, cheese made with aqueous or ethanolic ginger extracts had significant $(\mathrm{p} \leq 0.05)$ lower peroxide values compared with control and BHA cheeses at the end of storage period. The lower peroxide values of cheeses fortified with both ginger aqueous extract or ethanolic extracts may be due to antioxidant activity of ginger extracts. The peroxide values increased in different experimental cheeses as well as control with extended storage period up to the end of storage period. The obtained results are similar to those obtained by Omido et al., 2013 and Singh et al., 2013.
As storage period progress, the acid value increase gradually in all treatments as shown in table (3). This may be due to fat hydrolysis and liberation of free fatty acids, which cause gradual increase in rancidity during storage. The acid value of control cheese was higher significantly $(p \leq 0.05)$ than that of experimental cheese. Control cheese had the highest acid value followed by BHA treated cheese and finally cheese fortified with aqueous and ethanolic ginger extracts respectively. The obtained results are similar to those reported by Abd El-Aziz et al., (2012) and Omido et al., (2013).

Table 3. Oxidative stability of UF-soft cheese affected by addition of ginger extract.

\begin{tabular}{|c|c|c|c|c|c|c|}
\hline \multirow{2}{*}{ Properties } & \multirow{2}{*}{$\begin{array}{c}\text { Storage period } \\
\text { (days) }\end{array}$} & \multirow{2}{*}{ Control } & \multirow{2}{*}{$\begin{array}{c}\text { BHA } \\
(\mathbf{0 . 0 2 \%} \%)\end{array}$} & \multicolumn{2}{|c|}{ Ginger extract (1\%) } & \multirow{2}{*}{ Significant } \\
\hline & & & & Aqueous extract & Ethanolic extract & \\
\hline & Fresh & $0.76^{\mathrm{a}}$ & $0.70^{\mathrm{b}}$ & $0.67^{\mathrm{b}}$ & $0.63^{\mathrm{c}}$ & $* * *$ \\
\hline Acid value & 30 & $1.05^{\mathrm{a}}$ & $0.94^{\mathrm{b}}$ & $0.86^{\mathrm{c}}$ & $0.81^{\mathrm{c}}$ & $* * *$ \\
\hline \multirow[t]{2}{*}{ (mg KoH / g fat) } & 60 & $1.21^{\mathrm{a}}$ & $1.06^{\mathrm{b}}$ & $0.98^{\mathrm{c}}$ & $0.92^{\mathrm{d}}$ & $* * *$ \\
\hline & 90 & $1.43^{\mathrm{a}}$ & $1.27^{\mathrm{b}}$ & $1.20^{\mathrm{c}}$ & $1.14^{\mathrm{d}}$ & $* * *$ \\
\hline & Fresh & $4.74^{\mathrm{a}}$ & $4.28^{\mathrm{b}}$ & $4.21^{\mathrm{c}}$ & $4.20^{\mathrm{c}}$ & $* * *$ \\
\hline Peroxide value & 30 & $9.13^{\mathrm{a}}$ & $8.36^{\mathrm{b}}$ & $8.30^{\mathrm{b}}$ & $8.23^{\mathrm{c}}$ & $* * *$ \\
\hline \multirow[t]{2}{*}{$\mathrm{meq} / \mathrm{kg})$} & 60 & $13.44^{\mathrm{a}}$ & $12.65^{\mathrm{b}}$ & $12.51^{\mathrm{bc}}$ & $12.40^{\mathrm{c}}$ & $* * *$ \\
\hline & 90 & $19.00^{\mathrm{a}}$ & $13.95^{\mathrm{b}}$ & $13.68^{\mathrm{c}}$ & $13.51^{\mathrm{d}}$ & $* * *$ \\
\hline & Fresh & $0.158^{\mathrm{a}}$ & $0.144^{b}$ & $0.142^{b}$ & $0.137^{\mathrm{c}}$ & $* * *$ \\
\hline T.B.A. at & 30 & $0.165^{\mathrm{a}}$ & $0.157^{b}$ & $0.148^{\mathrm{c}}$ & $0.145^{\mathrm{c}}$ & $* * *$ \\
\hline \multirow[t]{2}{*}{$512 \mathrm{~nm}$} & 60 & $0.220^{\mathrm{a}}$ & $0.203^{b}$ & $0.192^{\mathrm{c}}$ & $0.184^{\mathrm{c}}$ & $* * *$ \\
\hline & 90 & $0.280^{\mathrm{a}}$ & $0.265^{b}$ & $0.250^{\mathrm{c}}$ & $0.243^{\mathrm{c}}$ & $* * *$ \\
\hline
\end{tabular}

$\overline{A, b, c}$ Means in the same row with different superseripts differ significantly at $(\mathbf{P} \leq \mathbf{0 . 0 5})$

The trend of the changes in Thiobarbituric acid values of all treatments was increased in all treatments with the progress in the storage period. The obtained results are similar to those obtained by Azzam, 2007. The ginger extract treatments were lower significantly $(\mathrm{p} \leq 0.05)$ in thiobarbituric acid compared to cheese treatments with synthetic antioxidant (BHA) and control cheese. Similar results were obtained by Bandyopadhyay et al. (2007).

Microbiological properties:

Data presented in Table (4) shows the total bacterial, coliform, yeast and mould counts of white soft cheese during storage period. The total bacterial counts decreased gradually in all treatments till the end of the 
storage period. Addition of ginger extracts reduced the total bacterial count than the control and BHA treatments along the storage period. This reduction may be attributed to the inhibitory effect of ginger extract as antimicrobial agent. These results agree with Onyeagba et al., 2004 and Lopez et al., (2017). Coliform bacteria were observed with slightly numbers at the beginning of the storage period in cheese samples, then not detected with the progress of storage period. This results are in agreement with Ekwenye and Elegalam (2005). The absence of coliform bacteria could due to the efficient heat treatment and good sanitation conditions applied during manufacture and storage of cheese samples and the development of acidity in cheese. These results agree with the results of Monzano, et al., (1992). Yeast and mould counts were not detected in all samples up to 60 days of storage except the control treatment which observed after 30 days of storage period this could be attributed to the inhibitory effect of ginger extracts. Also, it could be noticed that the yeasts and moulds were higher in control cheese compared with treated samples. These results agree with reported by Singh et al., (2005). Meanwhile counts of yeast, mould and coliform in all samples were in accordance to the legal Egyptian standards.

Table 4. Microbiological properties of UF-soft cheese affected by addition of ginger extract.

\begin{tabular}{|c|c|c|c|c|c|c|}
\hline \multirow{2}{*}{ Properties } & \multirow{2}{*}{$\begin{array}{c}\text { Storage period } \\
\text { (days) }\end{array}$} & \multirow{2}{*}{ Control } & \multirow{2}{*}{$\begin{array}{l}\text { BHA } \\
(0.02 \%)\end{array}$} & \multicolumn{2}{|c|}{ Ginger extract (1\%) } & \multirow{2}{*}{-Significan } \\
\hline & & & & Aqueous extract & Ethanolic extract & \\
\hline & Fresh & $43^{\mathrm{a}}$ & $40^{\mathrm{a}}$ & $28^{\mathrm{b}}$ & $25^{\mathrm{b}}$ & $* *$ \\
\hline Total viable count & 30 & $28^{\mathrm{a}}$ & $25^{\mathrm{a}}$ & $13^{\mathrm{b}}$ & $10^{\mathrm{b}}$ & $* * *$ \\
\hline \multirow[t]{3}{*}{ X $10^{6} \mathrm{Cfu} / \mathrm{g}$} & 60 & $12^{\mathrm{a}}$ & $10^{\mathrm{a}}$ & $6^{\mathrm{b}}$ & $5^{\mathrm{b}}$ & $*$ \\
\hline & 90 & $7^{\mathrm{a}}$ & $5 \mathrm{a}^{\mathrm{b}}$ & $3^{\mathrm{bc}}$ & $2^{\mathrm{c}}$ & $* *$ \\
\hline & Fresh & 2 & 1 & 1 & 1 & \\
\hline Coliform group & 30 & 1 & ND & ND & ND & \\
\hline \multirow[t]{3}{*}{$\mathrm{X} 10^{2} \mathrm{cfu} / \mathrm{g}$} & 60 & ND & ND & ND & ND & \\
\hline & 90 & ND & ND & ND & ND & \\
\hline & Fresh & ND & ND & ND & ND & \\
\hline Yeast \& mould & 30 & 2 & ND & ND & ND & \\
\hline \multirow{2}{*}{ X $10^{2} \mathrm{cfu} / \mathrm{g}$} & 60 & 6 & ND & ND & ND & \\
\hline & 90 & 23 & 12 & 2 & 1 & \\
\hline
\end{tabular}

$\overline{A, b, c}$ Means in the same row with different superscripts differ significantly at $(\mathbf{P} \leq \mathbf{0 . 0 5})$

\section{Organoleptic properties:}

The average score points of UF-white soft cheese are presented in table (5). The results showed that, organoleptic properties of all cheese treatments were improved by the progress of storage period until the end of storage period (90 days). On the other hand, there were significant differences $(\mathrm{p} \leq 0.05)$ between the control and all other treatments when fresh and during storage period. Cheese fortified with ginger extracts recorded the highest score points especially cheese made with ginger ethanolic extract. These may be due to proteolytic activity of ginger protease, which can improve the flavour and texture and also attributed to smell of gingerol and other volatile oils of ginger (Bandyopadhyay et al., (2007) and Vafopoulou et al., (1989).These results are in agreement with those reported by Abd El-Aziz et al,. 2012 \& 2015 who found that, addition of ginger extract to soft cheese gained the highest scores and became more acceptable to panelists than control cheese during storage, Adesokan et al., 2010 reported that addition of $5 \%$ ginger into Ogi cheese significantly improved its sensory properties. Finally, it was quite clear that cheese samples containing aqueous or ethanolic ginger extracts lead to reduce the undesirable changes in soft cheese compared to control cheese during storage period. The obtained results are similar to those reported by Bandyopahyay et al., (2008).

Table 5. Organoleptic properties of UF-soft cheese affected by addition of ginger extract.

\begin{tabular}{|c|c|c|c|c|c|c|c|}
\hline \multirow{2}{*}{$\begin{array}{l}\text { Storage period } \\
\text { (days) }\end{array}$} & \multirow{2}{*}{\multicolumn{2}{|c|}{ Properties }} & \multirow{2}{*}{ Control } & \multirow{2}{*}{$\begin{array}{c}\text { BHA } \\
(\mathbf{0 . 0 2} \%) \\
\end{array}$} & \multicolumn{2}{|c|}{ Ginger extract (1\%) } & \multirow{2}{*}{ Significan } \\
\hline & & & & & Aqueous & Ethanolic & \\
\hline \multirow{4}{*}{ Fresh } & Appearance & 10 & 7.50 & 7.50 & 8.00 & 8.00 & \\
\hline & Body \& texture & 40 & 36.80 & 36.70 & 36.87 & 36.90 & \\
\hline & Flavour & 50 & 44.70 & 44.75 & 45.81 & 45.85 & \\
\hline & Total & 100 & $88.00^{\mathrm{c}}$ & $89.05^{\mathrm{b}}$ & $90.68^{\mathrm{a}}$ & $90.75^{\mathrm{a}}$ & $* * *$ \\
\hline \multirow{4}{*}{30} & Appearance & 10 & 8.25 & 8.27 & 8.32 & 8.36 & \\
\hline & Body \& texture & 40 & 36.83 & 36.80 & 35.96 & 35.92 & \\
\hline & Flavour & 50 & 43.63 & 43.87 & 47.65 & 47.80 & \\
\hline & Total & 100 & $88.71^{\mathrm{c}}$ & $88.94^{\mathrm{b}}$ & $91.93^{\mathrm{a}}$ & $92.08^{\mathrm{a}}$ & $* * *$ \\
\hline \multirow{4}{*}{60} & Appearance & 10 & 8.30 & 8.32 & 8.40 & 8.45 & \\
\hline & Body $\&$ texture & 40 & 37.00 & 37.10 & 36.50 & 36.35 & \\
\hline & Flavour & 50 & 44.70 & 44.76 & 47.85 & 49.63 & \\
\hline & Total & 100 & $90.00^{\mathrm{d}}$ & $90.28^{\mathrm{c}}$ & $92.75^{\mathrm{b}}$ & $94.43^{\mathrm{a}}$ & $* * *$ \\
\hline \multirow{4}{*}{90} & Appearance & 10 & 8.00 & 8.35 & 8.42 & 8.50 & \\
\hline & Body $\&$ texture & 40 & 37.20 & 38.15 & 38.50 & 38.75 & \\
\hline & Flavour & 50 & 45.00 & 45.25 & 48.10 & 49.50 & \\
\hline & Total & 100 & $90.20^{\mathrm{d}}$ & $91.75^{\mathrm{c}}$ & $95.02^{\mathrm{b}}$ & $96.75^{\mathrm{a}}$ & $* * *$ \\
\hline
\end{tabular}

$\overline{\mathrm{A}, \mathrm{b}, \mathrm{c}}$ Means in the same row with different superscripts differ significantly at $(\mathbf{P} \leq \mathbf{0 . 0 5})$ 


\section{CONCLUSION}

It is notable that ginger aqueous or ethanolic extracts improved the oxidative stability and organoleptic properties of cheese up to 90 days compared to cheese contained BHA or control cheese. Therefore, it is preferred to ginger extract as natural antioxidant in manufacture of soft cheese with high quality.

\section{REFERENCES}

Abd El-Fattah, A.M. (2006). Lipolysis and oxidative stability of fat in ultrafiltrated white soft cheese containing vegetable oils. J. Agric. Sic.,Mansoura Univ., 31: 5193-5200.

Abd-El-Aziz M.; S.H. Mohamed; F. Seleet and M.A. L.Abd El-Gawad (2015). Effect of brine solution containing ginger extracts on the properties of Egyptian white brined cheese.American Journal of Food Technology,10 (1): 37-47.

Abd-El-Aziz, M.; S.H.S. Mohamed and E.L. Seleet, (2012). Production and evaluation of soft cheese fortified with ginger extracts as functional dairy food. Pol. J. Nutr. Sci., 62: 77-83.

Abdulla, A.E.M.; S.M. Darwish; E.H.E. Ayad and R.M. El-Hamahmy, (2007). Egyptian mango by product 2: Antioxidnt and antimicrobial activities of extracts and oil from mango seed kermel. Food Chem., 103: 1141-1152.

Adesokan, J.A.; O.P. Abiola and M.O. Ogundiya, (2010). Influence of ginger on sensory properties and shelflife of Ogi, a Nigerian traditional fermented food. African J. Biotechnol., 9:1803-1808.

Ajila, C.M.; R.A. Naidu; S.G. Bhat and U.J.S. Prasada Rao (2007). Bioactive compounds and antioxidant potential of mango peelextract. J. Food Chem., 105 (3): 982-988.

AOAC (2007).Official Methods of Analysis $15^{\text {th }}$ Ed. Association of Official Analytical Chemists INC. Arlington, Virginia, USA.

APHA, (2005).Methods for the Microbial Examination of Food.3rd Ed., vadderzant, Car and Donf.Splittsolesser (eds.) American Public Health Association, Washington D.C.

Azzam, M.A. (2007). Effect of partial replacement of milk fat with vegetable oils on the quality of processed cheese spreads. Egyptian J. Dairy. Sci., 35: 87-95.

Bandyopadhyay, M.; R. Chakraborty and U. Raychaadhuri, (2007). A process for preparing a natural antioxidant enriched dairy products (Sandesh). LWT-Food Sci. Thecnol., 40: 842-851.

Bandyopadhyay, M.; R. Chakraborty and U. Raychaadhuri, (2008). Antioxidant activity of natural plant sources in dairy dessert (sandesh) under thermal treatment. LWT Food Sci. and Technol., 41 (5): 816-825.

Bertolino, M.; S. Belviso; B. Dal Bello; D.Ghirardello; M. Giordano; L. Rolle and V. Gerbi, (2015). Influence of the addition of different hazelnut skins on the physicochemical, antioxidant, polyphenol and sensory propertiesof yogurt. LWT - Food Sci. and Technol., 63, 1145-1154.
Ekwenye, U.N. and N.N. Elegalam (2005). Antibacterial Activity of Ginger (Zingiber officinale) Roscoe and Garlic (Allium sativum L.) Extracts on Escherichia coli and Salmonella typhi. International Journal of Molecular Medicine and Advance Sciences, 1: 411417.

El-Sohaimy, S.A (2014). Chemical composition, antioxidant and antimicrobial potential of artichoke. The Open Nutr. J., 7:15-20.

Grant, K. L.; R. B. Lutz (2000). Alternative therapies: ginger. Am.J. Health-Syst. Pharm57, 945-947.

Hashim, MM; D. Mingsheng; M.F. Iqbal and C. Xiaohong (2011). Ginger rhizome as a potential source of milk coagulating cysteine protease. J. Phytochem. 72:458-464.

Huang, XW; L.J. Chen; Y.B. Luo; H.Y. Guo and F.Z. Ren (2011). Purification, characterization and milk coagulating properties of ginger proteases. J. Dairy Sci. 94:2259-2269j

Jang, H.A.; Y.P. Kim and H.S. Kim (2012). Effect of natural antioxidants on the oxidation of Microencapsulated seed oil. Food Control, 23 : 528 -534 .

Karaaslan, M.; M. Ozden,; H. Vardin and H. Turkoglu (2011). Phenolic fortification of yogurt using grape and callus extracts. LWT - Food Sci. technol., 44, 1065-1072.

Keeny, P.G. (1971). A guide to controlling oxidation in butter creams-candy and snack industry, 136 (7): 68.

Kosikowski, F.V. (1986). Cheese and Fermented Milk Foods. Edwards Brothers, Int. Michigan, USA.

Liang, M. H. (1992). From America: Cookbook medicine or food for thought: Practice guidelines development in USA. Ann. Rheum. Dis1992, 51, 1257-1258.

Lopez, E.I.C.; M.F.H. Balcázar; J.M.R. Mendoza; A.D.R. Ortiz; M.T.O. Melo; R.S. Parrales and T.H. Delgado (2017). Antimicrobial Activity of Essential Oil of Zingiber officinale Roscoe (Zingiberaceae). American Journal of Plant Sciences, 8, 1511-1524.

Martins, A.; L. Barros,; A.M. Carvalho; C. Santos-Buelga; L.P. Fernandes; F. Barreiro and I..C.F.R. Ferreira (2014). Phenolic extracts of Rubusulmifolius Schott flowers: characterization, microencapsulation and incorporation into yogurts as nutraceutical sources. Food Funct. 5, 1091-1100.

Monagas, M.; I.. Garrido; R. Lebron-Aguilar; M.C. Gomez-Cordoves; A. Rybarczyk; R. Amarowicz and B. Bartolome (2009). Comparative flavan-3-ol profile and antioxidant capacity of roasted peanut, hazelnut, and almond skins. J. Agric. Food Chem., 57: 10590-10599.

Monzano, M.; B. Citterio; G. Rondininl and M. Bertoldi, (1992). Microbiological aspects of natural starter in Montasio cheese making. Ann. Microbiol. Enzimol., 42 : 163-172.

Omido, R.V.; Lipoic and R. Melton, (2013). Preservation of sensory and chemical properties flavoured cheese prepared with cream cheese base using oregano rosemary essential oil. LWT Food Sci. and Technol. (53): 409-417. 
Onyeagba, R.A.; O.C. Ugbogu; C.U. Okeke and O. Iroakasi (2004). Studies on the antimicrobial effects of garlic (Allium sativum Linn), ginger (Zingiber officinale Roscoe) and lime (Citrus aurantifolia Linn). African Journal of Biotechnology Vol. 3 (10), pp. 552-554

Prasad, A.G.D. and H.N. Pushpa (2007). Antimicrobial activity of potato peel waste. Asian J. Microbiol., Biotechnol. and Environ. Sci., 9 (3): 559-561.

Prassad , N.K.; K.W. Kong; N.S. Ramannan; A. Azrina and L. Amin, (2012). Selection of experimental domain using two level factorial design to detdrmine extract yield, antioxidant capacity, phenolics and flavonoids from Mangifera pajang Kosterm, Sep. Sci. Technol., 47, 2417-2423.

Ramadan, M.F.; S.A. Mahgoub and R.M. El-Zahar (2014). Soft cheese supplemented with black curtim oil: Impact on food borne pathogens and quality during storage . Saudi J. Biol Sci. 21(3): 280-288.

Rehman, Z. U.; A. Salariya and F. Habib (2003). Antioxidant activity of ginger extract in sunflower oil. J. Sci. Food and Agri., 83: 624-629.

Reneer, E. and M.H. Abd El-Salam (1991). Application of Ultrafiltration in the Dairy Industry. Elsevir Applied Science, London and New York, P. 182.

Ruben, A. O.; V. Nepote and R. Nelson (2013). Preservation of sensory and chemical properties in flavoured cheese prepared with cream cheese base using oregano and rosemary essential oil. LWT. Food Sci. and Technol., $53: 409-417$.

Salem, S.A.; I.E. Gad-El-Rab and W.S. El-Sharaihy (2010). Improving the quality of fat soft cheese (Domiati) by incorporation whey protein concentrate. Proc. 11th Egypt. Conf. Dairy. Sci. and Technol., 145-162.
SAS (Statistical Analysis System). User's Guide (2003): Statistics, (SAS, Cary, North Carolina.).

Scott, R. (1981). Cheese making practice. Applied Sci. Puplisher Ltd. London.

Shori, A.B and A.S. Baba (2011 $)$ : Comparative antioxidant activity, proteolysis and in vitro $\alpha$ amylase and $\alpha$-glucosidase inhibitation of Allium sativum-yogurts made from cow and camel milk. Journal of Saudi Chemical Society 18 (5): 456-463.

Shori, A.B. and A.S. Baba (2011 $1_{\mathrm{a}}$ ). Antioxidant activity and inhabitation of key enzymes linked to typ-2 diabetes and hypertension by Azadirachta indicayogurt. Journal of Saudi Chemical Society 17 (3): 295-301.

Singh, G.; S. Maurya; C. Catalan and M. P. deLampasona (2005) Studies on Essential Oils, Part 42: Chemical, Antifungal, Antioxidant and Sprout Suppressant Studies on Ginger Essential Oil and Its Oleoresin. Flavour and Fragrance Journal, 20, 1-6.

Singh, V.K.; L.A. Beattie and T.M. Seed (2013): Vitamin E: Tocopherols and tocotrienols as potential radiation countermeasures. J. Radiat Res. 54 (6): 973-988.

Vafopoulou, A.; E. Alichanidis and G. Zerfiridis, (1989). Accelerated ripening of Feta cheese with heatshocked cultures and proteinases. J. Dairy Res., 56: 285-296.

Yean, Y.S. and J.B. Phillip (2004). Antioxidant activity and phenolic content of selected fruit seeds. J. Food Chem., 88: 411-417.

Zancan, K.C.; M.O.M. Marques; A.J. Petenate and M.A.A. Meireles, (2002). Extraction of ginger (Zingiber officinale Roscoe) Oleoresin with $\mathrm{CO}_{2}$ and cosolvents: A study of the antioxidant action of the extracts. J. Supercritl. Fluids, 24: 57-76.

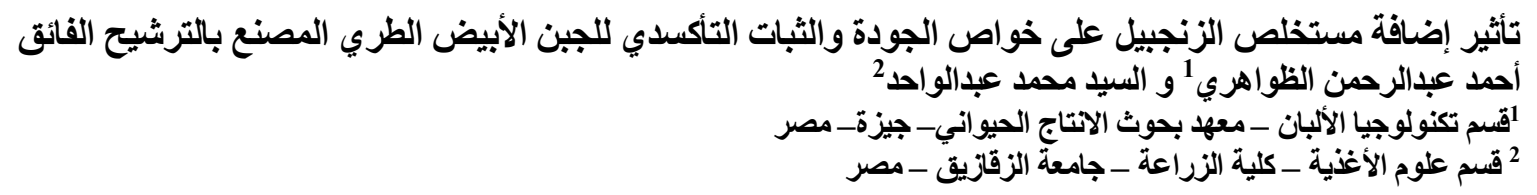

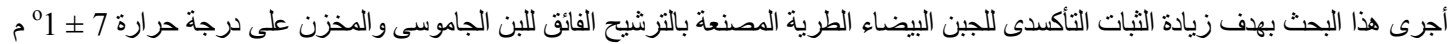

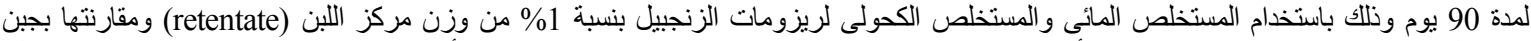

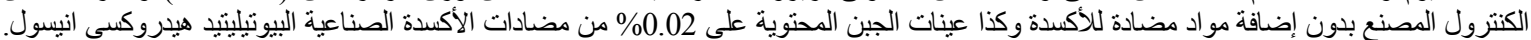

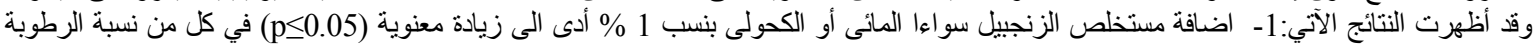

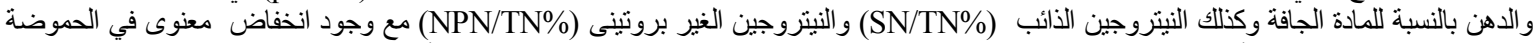

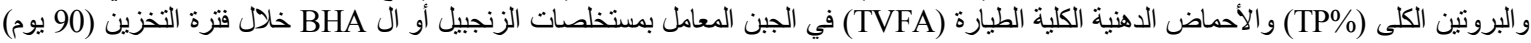

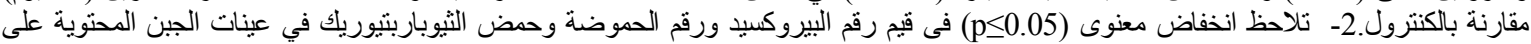

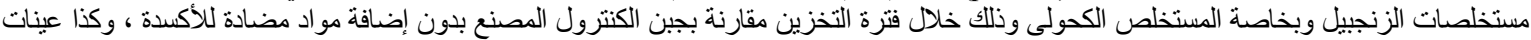

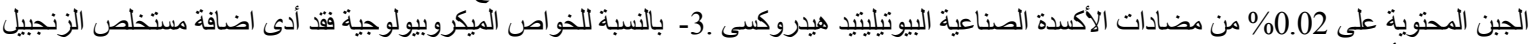

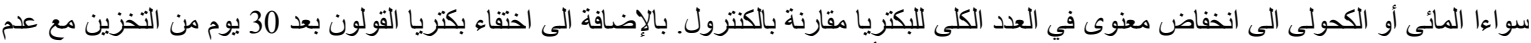

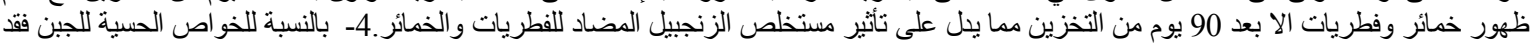

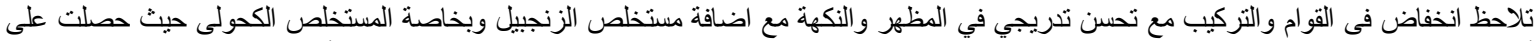

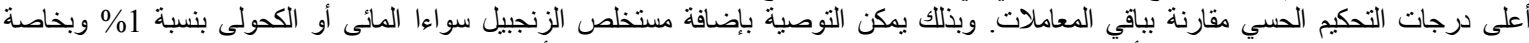
المستخلص الكحولى عند تصنيع الجبن الأبيض الطرى بالترشيح الفائق مما يحسن من جودتها وثنباتها التأكسدى. بأنسات 